ÉGYPTE

monde arabe

\section{Égypte/Monde arabe}

$10 \mid 2013$

Les élections de la révolution (2011-2012)

\title{
Revolutionary, creative, heterogeneous and unorganized: young Egyptians facing elections
}

\section{Azzurra Meringolo}

\section{(2) OpenEdition}

\section{Journals}

Édition électronique

URL : https://journals.openedition.org/ema/3132

DOI : 10.4000/ema.3132

ISSN : 2090-7273

\section{Éditeur}

CEDEJ - Centre d'études et de documentation économiques juridiques et sociales

\section{Édition imprimée}

Pagination : 111-127

ISBN : 978-2-905838-81-0

ISSN : 1110-5097

\section{Référence électronique}

Azzurra Meringolo, «Revolutionary, creative, heterogeneous and unorganized: young Egyptians facing elections », Égypte/Monde arabe [En ligne], 10 | 2013, mis en ligne le 10 février 2014, consulté le 07 juillet 2022. URL : http://journals.openedition.org/ema/3132 ; DOI : https://doi.org/10.4000/ema.3132

Ce document a été généré automatiquement le 7 juillet 2022.

Tous droits réservés 


\title{
Revolutionary, creative, heterogeneous and unorganized: young Egyptians facing elections
}

\author{
Azzurra Meringolo
}

1 For decades, Egyptian presidents used the expression ibnâ'î, i.e. my sons, when they referred to the population they represented. Eighteen months after Mubarak's fall, the neo-elected president Mohammed Mursi preferred to address to them as al-muwâtinîn, i.e. citizens. If even maybe only to some extent, Mursi's refusal to use the patriarchal vocabulary of his predecessor reflects an important change in Egyptian political frame. Those Egyptians who did not accept to be called sons by their dictator became every day more and more active in the political arena, transforming their passivity into participation. Among these new citizens we find, above all, young people, who made their debut in Egyptian political life.

Based on a fieldwork, this paper investigates which role revolutionary Egyptian youth ${ }^{1}$ played in the electoral process. Even if some revolutionaries questioned the validity of these elections organized under military rule, for the first time in their life, many young revolutionary Egyptians showed a political activism never seen before. To sum up, this work focuses on an urban context and tries to investigate the role, the strategies and the contribution young Cairo activists gave to the electoral process.

With the help of an interdisciplinary approach, and using a wide selection of flyers, debates records (television, radio, live conferences and informal meetings), personal interviews, newspaper articles, social networks' posts, street graffiti and artistic productions as primary sources, this research highlights different aspects of a very complex reality.

\section{Egyptian youth facing transition's challenges}

4 Asmaa Mahfouz, Ahmed Maher, Wael Ghoneim and other young women and men who organized and took part in 2011 revolt, grew up in the 90's, when first neo-liberal 
economic policies were implemented. These measures showed their uselessness came of age during the last decade, when the consequences of privatization and economic deregulation were evident and when the International Monetary Fund's austerity interventions and the World Bank's structural-adjustment programs - established to favor foreign donors and creditors - started to show their negative effects. Even if liberalization and privatization processes determined positive macro-economic data in 2002-2006, Egypt's GDP increased 5\% and in 2007 it reached its peak with $7 \%^{2}$ - there was a constant deterioration of labor market conditions that squeezed the middle class and young people. Youth unemployment rate increased from $9.8 \%$ in 1998 to $14.4 \%$ in $2006^{3}$.

5 Although the revolt had a transgenerational feature, in such a delicate situation and pushed by discontent ${ }^{4}$, the young generation became the main protagonist of the revolt. During the last ten years, young Arabs gradually took conscience of important socio-cultural issues and started to play a major role in politics through new opposition forms. We witnessed to what Asef Bayat called a "non-social movement", able to transform itself in a more structured organization or in a simple political movement according to events. Bayat talks about collective actions taken by non-collective actors, in the sense that a large number of ordinary people triggered a deeper social change, even though these actions were rarely guided by an ideology or recognizable leaderships and organizations ${ }^{5}$. Moreover, non-collective actors used all means available, as well as courage and creativity, to raise their voice, facing all kinds of difficulties just to be heard, seen and to express their concern ${ }^{6}$.

The leading role of young people cannot be fully understood without considering both the human development rates presented by UN-sponsored reports in 2003 and the growth in the use of Internet in the region. Supported by the UNDP ${ }^{7}$, the Arab Human Development Reports stated that the Arab cultural production of these past few years represented an economic resource for a large number of young people and that the Web was one of the most important means of cultural improvement. Between 2002 and 2008 , in the Arab world the use of the Web increased $1176.8 \%$, compared to $290 \%$ for the rest the world, and in 2010 Egypt's Internet users were the highest number in the region, counting 12,568,900 Egyptians, 18.7\% of all Arab Internet users ${ }^{8}$.

7 As one of the main actors in the old regime's overthrow, young people gained the admiration of many Egyptian citizens, of all ages. Although the generation gap often takes a stereotyping form - "our" generation versus "theirs", the "fearful" generation versus the "courageous" one - social divisions were left aside to give room to a new connection between old and young people?

8 Before and during the first phase of the revolution, young protesters were not linked to Islamist movements. Bayat, indeed, talked about post-Islamist revolution, a sort of indigenous political reform marked by a blend of democratic principles and, possibly, religious sensibilities ${ }^{10}$. Nevertheless, after Mubarak's fall and with the birth of Islamist (hizb Al-Hurriya wal-'Adâla) and Salafist (hizb Al-Nûr) parties, young revolt initiators and well-known young representatives started to use the Web as a real political tool. At first, the Web was a unifying arena used to spread subversive messages and organize secret meetings but then, during the transitional period, it became a platform for a wider debate and a virtual space where to share more articulated political messages.

During the first days of transition, the heterogeneous group of young Egyptians, the core of the street's revolt, had to deal with issues regarding its structure, such as its 
internal organization and the lack of leadership. In fact, favoring an informal political participation, to some extend this group distanced itself from the classical, organized opposition scheme. In contrast to the worn-out forms of party affiliation in the Arab world, young Egyptians set a new, spontaneous model of political engagement, as many other young Arabs during the Springs. Divisions, once again, sneaked in the youth movement, which split into multiple expressions - youth groups, political parties, bloggers and Internet activists, civil society organizations - mostly uncoordinated, divided by ideological, strategic and social differences ${ }^{11}$. Certainly, the main characteristics of the Egypt's youth movement - flexibility, decentralization, ideological heterogeneity of their members, use of new technologies to communicate were the major strength during the anti-Mubarak's protest because they involved a large number of young people without any political affiliation, unifying young Egyptians against the regime and accelerating a break with the old system ${ }^{12}$.

At the same time, these factors became elements of weakness when young Egyptians decided to approach the electoral dynamics. Due to their political inexperience and inability to transform their revolutionary message into political practice, final election results did not represent a success for young people in their first appointments with the ballots. Nevertheless, it would be unfair to judge youth contribution to the transition by only looking at the electoral performances. Thus, considering youth participation to the political process as one of the most innovative element in the Egyptian Spring, this paper underlines the great contribution young revolutionary Egyptians gave to the electoral process, influencing its debates and taking part to all its stages through political pluralism and original strategies.

\section{Ready for electoral debut}

11 This paper focuses on one of the most important and active aspects of political participation: elections. In this paragraph, great attention will be given to parliamentary elections because young activists had more opportunities to take part in the electoral process in this particularly important appointment than in the previous referendum and the following presidential elections. Some young revolutionary forces, such as shabâb al-thawra, the Revolution Youth Coalition (RYC), showed their limits and weaknesses.

RYC took its first steps in Tahrir square, in early February 2011, and more than twenty five political movements, parties and groups were involved in it, as well as independent activists and protesters who chose this coalition to be the voice of their revolutionary demands ${ }^{13}$. Even if all these movements agreed about major requests - bread, freedom and social justice - they soon faced problems that undermined the coalition's stability. According to the blogger Zeinobia, the biggest RYC's "sin" was to limit the revolt to Tahrir square, neglecting the population's demands. Moreover, all members could not overcome their political principles and differences to reach common goals ${ }^{14}$. Thus, at the beginning of the parliamentary election process, coalition participants enrolled in different parties and its power sharply decreased.

More than fifty RYC members ran for parliamentary elections, a quarter of the number the Coalition announced during a press conference in September 2011 at the syndicate of journalists in Cairo. In this occasion, RYC also called for an electoral coalition of revolutionaries to fight against members of the old regime who were trying to stay in 
power. Among RYC candidates, there were also former MB youth members, such as Islam Lofty, founder of Al-Tayyar Al-Masri - Egyptian Current Party - that, running in the Giza district, stands for a centrist and more liberal version of Islamic politics. In addition, some candidates ran both as RYC affiliates and as independents, like blogger and activist Abdel Rahman Fares who run in Fayoum. Among the names belonging to the revolutionary forces should be mentioned other candidates from the Al-'Adl Justice - party, such as Mustafa El Naggar and Ahmed Shoukry, former members of the National Front for Change. Different from other young candidates, Shoukry ran in a district out of Cairo ${ }^{15}$. Coming from a famous family of politicians, he was one of the few young candidates that already had some kind of experience in politics because he previously ran, unsuccessfully, in 2010 elections. Among Al-'Adl candidates, there was also Dalia Zaida, and the award-winning journalist and blogger, executive director of the Cairo-based Ibn Khaldun Centre for Development Studies. One of the youngest revolutionary candidates was the twenty-five year old Mahmûd Mubârak, who ran for elections in the heart of Upper Egypt big clans, in Qena district.

Well known bloggers and activists, under different political flags, took part in what were perceived as the most important elections in Egypt's modern history since the 1920s. Heliopolis district provides an example of competition among revolutionary candidates. Blogger Mahmoud Salem, also known as Sandmonkey, ran against Asmaa Mahfouz, the activist famous for her Youtube video, that helped mass demonstrations to spark off, one week before the beginning of the revolt. In the same district we find Amr Hamzawy too. Even if he was older than the other two bloggers, this Westerneducated political analyst was considered part of the revolutionary movement. The increasing competition is one of the elements that showed how the presence of these three candidates split the vote ${ }^{16}$. The race was finally won by Hamzawy, but the competition was in part influenced by Mohamed Mahmoud's street clashes that took place between the army and the revolutionaries, one week before the elections. Even if the ballot papers had already been printed, Mahfouz declared the withdrawal of her candidacy. An increasing number of young revolutionaries that previously declared to support Salem called for the boycott of elections held under military rule and in such a violent mood. "It is not possible to think that our first free elections take place in such an atmosphere" said in a personal interview Shahir George Ishâq, another young revolutionary candidate from Kefaya ${ }^{17}$, running in the East Cairo district for the AlMasriyyin Al-Ahrâr - Free Egyptians - party. Nevertheless, in this occasion the boycott movement did not significantly influence the overall process, the majority of revolutionary candidates in the end decided to run and young electors went to the polls.

15 Even if at the end their results were not successful, young revolutionaries' political involvement represents an historical record that will be important for future elections. It also confirms that, when the revolt left room to political competition, the heterogeneous group of revolutionaries that had been ready to fight against the big common enemy, was not able to stay under the same political flag. In its dissolution communiqué, published on July $8^{\text {th }}$, RYC admitted that its participation to the elections was not a success :

The Coalition at the time was not able to enter the elections as a group. Some of its members preferred to enter the elections on the Egyptian Bloc list, and some others on the Revolution Continues Alliance list; some entered the elections running for independent seats. This was not conducive to creating a situation whereby 
everyone that might have been nominated for the list of a single electoral alliance

could have run in the elections ${ }^{18}$.

\section{Supporting presidential candidates}

16 Young revolutionary candidates were not the only ones the Egyptian youth decided to support. sometimes, young people preferred to vote for older candidates who, still considered revolutionary, were perceived more prone to success. Amr Hamzawy and Amr Shobaki, the director of the Arab Forum for Alternative who ran as a liberal independent, were two of the most supported parliamentary candidates. Also Gamila Ismail, a hardened political activist, TV journalist and ex-wife of opposition leader Ayman Nour, received the support of young revolutionaries and an important number of young women decided to take part in her campaign.

Moving from parliamentary to presidential elections, Bouthayna Kamel was another woman who received support from young people. An anti-regime and anti-military journalist, Kamel is also founder of Shayfeen - we are watching you - an organization that spreads awareness on political institutions. She wanted to become the first female candidate in the history of Egyptian presidential elections, but she did not collect sufficient votes to present her candidacy and she finally supported Hamdeen Sabbahi. Together with Abdel Monein Aboul Foutouh and Khaled Ali, Sabbahi was the young revolutionaries' favorite candidate.

Observing RYC's behavior, since the beginning it was clear that there was a group - AlTayar Al-Masri - that supported Aboul Foutouh, and another one that did not promote any particular candidate. With the help of a number of public figures, this second group tried to set up a presidential team that gathered all revolutionary candidates together. Neither these attempts nor the sessions held with the five major candidates were helpful. As a result, some members chose to boycott the elections, some others continued to support Aboul Foutouh. At a later time, when the idea of a presidential project seemed already failed, the rest showed their support for Hamdeen Sabahi ${ }^{19}$.

Concluding campaign events confirmed division among young revolutionaries. On May $18^{\text {th }}$, Aboul Foutouh met his supporters at the Al-Gazeera Youth center in Zamalek, during an event attended by a cross-section of Egyptian population. Middle class, liberal and moderate Islamist families, as well as young Christians, went on a march to reach the center. Youth presence was impressive and, during the meeting, Aboul Foutouh received the endorsement of activist Wael Ghonim, considered one of the most important organizers of the January 25th demonstration. Visiting Sabbahi's headquarters, it was evident that the majority of people involved in his campaign were young Egyptians that took part in the revolt, members of April 6th movements, Kefaya activists and nationalists. The role of young people was also clear on the bus tour across Cairo districts that closed Sabbahi's campaign. "Officially our movement did not support any candidate, but the majority of us is campaigning for Hamdeen. He is the only one able to achieve Tahrir goals" said in a personal interview Mona, an April 6th member, part of the bus staff. Some hours later, also another young woman at Amr Moussa press conference described herself as an April 6th member and supporter of Moussa. When a journalist asked her to provide further details about her role in the movement, she declined to answer, rising doubts about the honesty of her words. This episode confirms that, speaking in the name of revolutionary forces became a common 
attitude shared by all candidates. Nevertheless, covering the campaign, it was evident that those who attended Moussa ${ }^{20}$ and Ahmed Shafîq's conferences were not as young and revolutionary as the Sabbahi and Fothou's supporters.

The first turn's results were perceived as a failure and they threw young revolutionaries into such confusion that the number of those who called for a boycott increased $^{21}$, as doubts and debates. Both Shafîq and Moussa ${ }^{22}$ were perceived as the less revolutionary candidates. Young Egyptians faced three options : boycott, invalidate their vote or choose Mursi. The majority of RYC's members decided to boycott, but some from the Al-Tayyar Al-Masri and April $6^{\text {th }}$ finally supported Mursi. His electorate increased and, on the eve of the run-off, the Egypt's highest court declared the Parliament invalid and the country's interim military rulers promptly took full legislative authority, triggering chaos and confusion about the leadership. Sarah AlSirgany was one of the revolutionary activists who openly explained why she chose to support Mursi :

Even if [he] wants to model Egypt to the Saudi or Iranian conservatism, which is socially, economically and politically impossible, it would take them more than ten years to do so. Any new president from outside the regime will have to battle second, third and fourth-tiers of regime beneficiaries, even just to replace them with equally corrupt but loyal officials. Taking over power, much less enforcing a complete social and political change, would take years ${ }^{23}$.

Blogger Zenobia had a similar opinion:

If I want to revolt against Mursi, [rather than Shafîq] it will be much easier to get support from the army and the police as well many sectors in the society. I voted for Mursi and I hate and refuse the Muslim Brotherhood and their program (...) I know that I will be opponent to him and his brotherhood ${ }^{24}$.

As shown by the posts, both Al-Sirgany and Zeinobia considered Mursi a less dangerous candidate and a more distant figure to the previous regime. Thus, the lesser of the two evils. With a heavy heart and with small hope that their vote really helped Egypt's transition, from the first day of Mursi's presidency, Egyptian young revolutionaries started to reorganize themselves to find a democratic strategy through which they could achieve all Tahrir's goals.

\section{Revolution watchdogs}

While participating and supporting different candidates, revolutionary Egyptian youth constantly watched over the revolt's evolution. During the transition, young revolutionaries strongly criticized the Security Council of Armed Forces' (SCAF) behavior, denouncing the candidacy of some people linked with the old regime, and following voting and counting operations. Carrying out original and creative activities, they continued their supervisory activity even after Mursi's victory.

Activists decided to use their cameras as a weapon to show soldiers' misbehavior and criticize army's violence. During October and December 2011 clashes in Mohamed Mahmoud and Qasr Al-Aini streets, Hossam Al-Hamalawy used his blog and twitter account to repeat one of his slogans to his followers: "In dictatorship, independent journalism by default becomes a form of activism, and the spread of information is essentially an act of agitation ${ }^{25 "}$. 
In the same period, a group of activists who wanted to denounce SCAF's transgressions started a new campaign called 3askarKazeboon - soldiers are liars. The main goal of this campaign was evident: to show the atrocities perpetrated by the army. But 3askarKazeboon also implicitly highlighted the importance of public space and its use to voice political dissent. The idea was simple and easy to put in practice. Activists chose a place where to screen all videos, graffiti stencil models and pictures regarding human rights abuses. The only thing left to do was hyping the event on Twitter and Facebook. Usually the event started out with a screening of the videos, followed by marches through the streets of Cairo. Citizens held pictures and distributed website stickers of the campaign and fliers to bystanders, passing cars and pedestrians. This was usually accompanied by conversations and debates with skeptical and curious citizens. 3askarKazeboon spread across the entire country. In this case too, its organizers belonged to a completely decentralized movement with no hierarchy. According to Omar Al-Sabh, a political sciences' student at the American University in Cairo :

A year after the initial uprising, we are still drenched in a war of information. It is unfortunate that there are some who believe that the revolt is over. However the truth of the matter is that we are still struggling against a state and a system that refuse to raze the establishment of exerting power through violence. Alternative media, strategic use of public space, civilian marches, and the internet are the only tools that the revolutionary force has at its disposal to affect change ${ }^{26}$.

During the parliamentary elections' campaign, political groups and activists including April 6th and RYC also launched Emsekflol.com, a website that listed members of exNational Democratic Party ${ }^{27}$ (NDP) leaders and important candidates, local councils and NDP headquarters in all Egyptian governorates. The website also includes the names of those parties founded by the fulul, the NDP remnants.

The struggle against the fulul continued during the presidential campaign, when revolutionary activists strongly criticized Moussa and Shafîq's candidacy. A couple of days before the elections, Cairo's graffiti artists offered a sarcastic rebuttal of city's authorities, painting a fulûl graffiti on Mohamed Mahmoud's wall, combining the faces of various figures together. Half of it represented Marshall Tantawi, and the other half Hosni Mubarak. Behind them, stood Moussa and Shafî $q^{28}$.

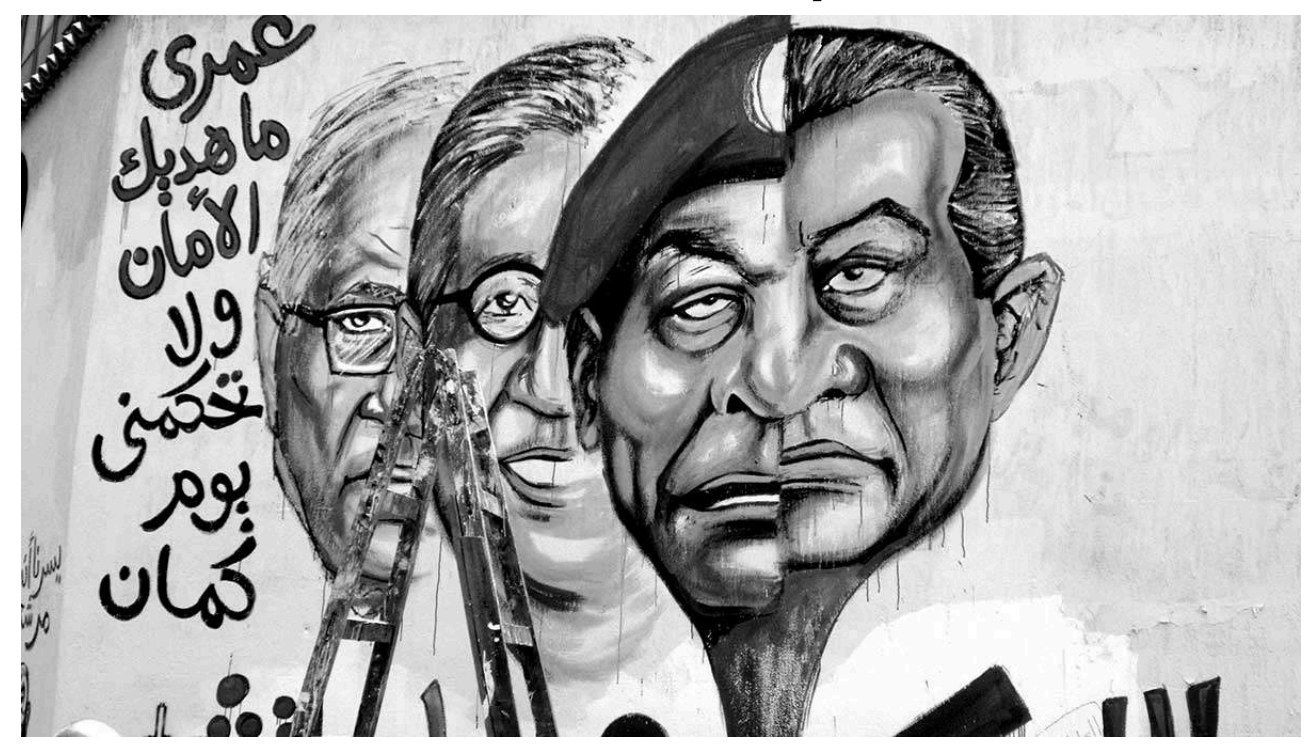



played an important role in the electoral process too. After decades of political disaffection, their participation was one of the most innovative aspects in voting. With different intensity, involvement and forms, they took part in the political scenario as an informal and spontaneous protagonist, even if they showed to be a heterogeneous group divided by different political ideas and strategies. Although they appeared uncoordinated and unorganized, they all desired to make the difference in the transitional process.

least in urban areas, their enrollment really influenced politics, organizing campaigns and facing ballots. In addition, aware of the transition's risks and mindful of the recent past of the country, they became the revolution caretakers. Thanks to activism, fantasy, ability with arts and technology, they used original strategies that, together with the more traditional ones, turned out to be strong weapons for their struggle. 

to the presidential elections more divided and without a common candidate Nevertheless, most recent debates have shown that there is a wide ongoing reflection among young revolutionaries who, unsatisfied with the election results, wanted to work together and create a coalition that could represent their interests. RYC's declarations show that they are aware of their ideological heterogeneity, they know that decentralization and the lack of leadership became elements of weakness when it was time to approach electoral dynamics. young members have to face some challenges. Will they be able to conduct their opposition role in a democratic - internally and externally - way? How will they transform ideas into effective political actions? Will they be able, saving their flexibility, to coordinate their strategies and find a winning one? Will they pass from squares to political institutions? And if so, how will they use their original weapons in traditional politics?

After decades of disaffection, youth contribution to political life is something extremely good for Egyptian society. According to the novelist Alaa Al-Aswany, "for too many decades Egypt was a country sitting on the bench. A corrupted coach took to the field the eldest player, leaving the best on the bench. These one have incredible potential, but they never had the opportunity to play. ${ }^{31}$ " Nowadays they have this opportunity but, before winning, they still need to practice.

\section{BIBLIOGRAPHIE}

ACHCAR G., 2009, “Egypt's Recent Growth: An “Emerging Success Story?”, Development Viewpoint, $\mathrm{n}^{\circ} 22$, p. 1 .

ASSAAD R., 2007, “Labor Supply, Employment And Unemployment In The Egyptian Economy, 1988-2006", in ASSAAD R. (ed.), The Egyptian Labor Market Revisited, Cairo, American University in Cairo Press, p. 1-53.

BAYAT A., 2010, Life as Politics. How Ordinary People Change the Middle East, Amsterdam, ISIM/ Amsterdam University Press.

Cоцомво S., 2012, "Giovani e democratizzazione in Egitto dopo la Primavera araba: un nuovo paradigma di partecipazione politica?”, Rivista Italiana di Sociologia, vol. 3, n 5, p. 55-69.

EL-Sновакі A., May $2^{\text {nd }} 2010$, “Parties, Movements and prospects for change in Egypt", Arab Reform Bulletin, http://carnegieendowment.org/sada/2010/05/20/parties-movements-and-prospectsfor-change-in-egypt/6c04

KoRANY B., 2010, The Changing Middle East: A New Look at Regional Dynamics, Cairo, American University of Cairo Press.

PACIELlo M. C., 2011, La Primavera Araba: Sfide e Opportunità Economiche e Sociali, Roma, Consiglio Nazionale per l'Economia e il Lavoro.

Égypte/Monde arabe, 10 | 2013 
PINTAK L., 2007, "Reporting a revolt: the changing Arab media landscape", Arab Media and Society, $\mathrm{n}^{\circ}$ 1, http://www.arabmediasociety.com/?article=23

SHAHINE S. H., 2011, "Youth and the revolution in Egypt", Anthropology Today, vol. 27, n 2, p. 1-3.

UNITED NATION DEVELOPMENT PROGRAM, 2003, Arab Human Development Report 2003, http://

hdr.undp.org/en/reports/regionalreports/arabstates/Arab_States_2003_en.pdf.

\section{NOTES}

1. If not specified, when I refer to Egyptian youth, I talk about revolutionary Egyptian young people.

2. Gilbert Achcar, “Egypt's Recent Growth: An 'Emerging Success Story?’”, Development Viewpoint, $n^{\circ} 22,2009$.

3. Ragui Assaad, "Labor Supply, Employment And Unemployment In The Egyptian Economy, 1988-2006", in R. Assaad (ed.), The Egyptian Labor Market Revisited, Cairo, American University in Cairo Press, 2007, p. 17.

4. Silvia Colombo, "Giovani e democratizzazione in Egitto dopo la Primavera araba: un nuovo paradigma di partecipazione politica?", Rivista Italiana di Sociologia, vol. 3, n 5, 2012, p. 57.

5. Asef Bayat, Life as Politics. How Ordinary People Change the Middle East, Amsterdam, ISIM/ Amsterdam University Press, 2010, p.14.

6. Ibid., p. 26.

7. United Nation Development Program, Arab Human Development Report 2003, http:// hdr.undp.org/en/reports/regionalreports/arabstates/Arab_States_2003_en.pdf, (Last access September 2012).

8. Internet World Stats, http://internetworldstats.com/, (Last access September 2012).

9. Selim H. Shahine, "Youth and the revolution in Egypt", Anthropology Today, vol. 27, n 2, 2012, p. 2.

10. A. Bayat, op. cit., p. 14.

11. S. Colombo, op. cit., p. 63-64.

12. Maria Cristina Paciello, La Primavera Araba: Sfide e Opportunità Economiche e Sociali, Roma, Consiglio Nazionale per l'Economia e il Lavoro, 2011, p. 58.

13. It was formed by several politically oriented movements, such as liberal - El-Baradei support campaign, Democratic Front Party and April $6^{\text {th }}-$, Islamist - Muslim Brotherhood (MB), MB Youth and ex-MB Youth -, leftist - Revolutionary Socialists, Tagammu' Party Youth -, and socialdemocratic - Justice and Freedom Youth.

14. "Farewell Revolt Youth Coalition", Egyptian Chronicles, July $2^{\text {nd }} 2012$, http:// egyptianchronicles.blogspot.it/2012/07/farewell-revolt-youth-coalition.htm,l (Last access September 2012).

15. The same did Abdel Rahman Ezz.

16. At the beginning, Salem was running as an independent candidate but, as soon as he understood that he needed the support of campaigners, he joined the Al-Masriyyin Al-Ahrar, the Free Egyptian party led by the Coptic tycoon Naguib Sawiris, and he officially faced Hamzawy, the candidate of Misr Al-Hurra, the Egypt Freedom party (See the article of Giedre Sabaseviciute in this issue).

17. Ishâq is the son of the Coptic founder of Kefaya, the Egyptian movement for change which, prior to the 2011 revolution, was supported by many Egyptian's political organizations. Kefaya was founded in 2004 as a platform to protest against Mubarak's presidency and the possibility he might seek to transfer power directly to his son, Gamal ; it was against political corruption and stagnation too. 
18. This declaration was posted on the coalition's Facebook page on July $8^{\text {th }}$, https:// www.facebook.com/photo.php?fbid $=422755627776801 \&$ set $=a$.

165714020147631.50568.165263783525988\&type=1, (Last access October 2012).

19. Ibid.

20. Before the first run, young revolutionaries described both Shafîq and Moussa as fulûl, remnants of the old regime, but after the run-off, they declared that Moussa was not so involved in Mubarak's circles.

21. Final official turn-out statistics did not show a lower turnout in run-off elections.

22. The first one was a former Egyptian Foreign Minister and Secretary General of the Arab League, and the latter was Prime Minister during the last Mubarak's government.

23. Sarah el-Sirgany, "Why I'm voting”, June $17^{\text {th }}$ 2012, Egypt Monocle, http://egyptmonocle.com/ Emonocle/why-im-voting/, (Last access October 2012).

24. Zeinobia, "Voting girl: 2012 Presidential Election", June 17 $7^{\text {th }} 2012$, Egyptian Chronicles (Blog post), http://egyptianchronicles.blogspot.it/2012/06/voting-girl-2012-presidentialelections.html, (Last access October 2012).

25. Arabawy, (Blog post), http://www.arabawy.org/, (Last access October 2012).

26. Al-Masrî Al-Yawm, January $18^{\text {th }}, 2012$.

27. Hosni Mubarak's party.

28. Cairo authorities removed the original drawing with Tantawi and Mubarak only. So artists repainted it adding Moussa and Shafîq in the background.

29. Al-Ahram on line, September $23^{\text {rd }}$ 2012, http://english.ahram.org.eg/NewsContent/ 5/32/53436/Arts-Culture/Film/Mosireen-Media-Collective-calls-for-donations-onli.aspx, （Last access September 2012).

30. Al-Masrî Al-Yawm, June $25^{\text {th }} 2012$.

31. Personal interview, February $16^{\text {th }} 2011$.

\section{RÉSUMÉS}

Cet article examine le rôle joué par la jeunesse égyptienne dans le processus électoral. Même si certains révolutionnaires ont contesté la validité d'élections organisées sous un régime militaire, beaucoup de jeunes révolutionnaires égyptiens ont fait montre à cette occasion d'un militantisme politique jamais vu auparavant. Centré sur le milieu urbain, cette étude s'intéresse au rôle, aux stratégies et aux contributions apportées par les jeunes militants cairotes aux différentes étapes du processus électoral. Leurs modes de participation ont constitué l'un des aspects les plus innovants de ces élections, et bien qu'ils soient apparus non-coordonnés et inorganisés, ils ont tous cherché à faire la différence dans le processus de transition. Grâce à leur militantisme, leur imagination, et leurs compétences artistiques et technologiques, ils sont devenus les gardiens de la révolution et ont développé des stratégies originales qui, combinées avec des stratégies plus traditionnelles, se sont révélées des armes efficaces dans leur combat.

This paper investigates which role revolutionary Egyptian youth played in the electoral process. Even if some revolutionaries questioned the validity of elections organized under military rule, for the first time in their life, many young revolutionary Egyptians showed a political activism never seen before. Focused on an urban context, this work investigates the role, the strategies and the contribution young Cairo activists gave to all the different steps of the electoral process. 
Their participation was one of the most innovative aspects in voting, and although they appeared uncoordinated and unorganized, they all desired to make the difference in the transitional process. Thanks to activism, fantasy, ability with arts and technology, they became the revolution caretakers and they used original strategies that, together with the more traditional ones, turned out to be strong weapons for their struggle.

\section{INDEX}

Mots-clés : jeunesse égyptienne, chabâb al-thawra, élections égyptiennes, 6 avril, jeunesse révolutionnaire

Keywords : Egyptian youth, Shabâb al-thawra, Egyptian election, April 6th, Revolutionary youth

\section{AUTEUR}

\section{AZZURRA MERINGOLO}

Azzura Meringolo est docteur en relations internationales. Journaliste et chercheuse, elle s'est établie au Caire durant l'été 2010 et a rejoint le CEDEJ pour une recherche de terrain portant sur l'anti-américanisme égyptien après le 11 Septembre. Sa thèse a reçu le prix Maria Grazia Cutuli. Elle a couvert les événement qui ont conduit à la révolution du 25 janvier 2011 pour le compte de journaux italiens et internationaux. Elle a publié en juin 2011 un livre intitulé I ragazzi di Piazza Tahrir. En 2012, elle a obtenu le prix du journalisme Ivan Bonfanti pour l'un de ses reportages. Elle est coordinateur scientifique pour Arab Media Report et chercheuse à l'IAI, Istituto Affari Internazionali.

Azzurra Meringolo holds a PhD in international relations. Engaged in journalism and research, in Summer 2010, Azzurra landed in Cairo and joined the CEDEJ for her field research on post 9-11 Egyptian anti-

Americanism. With her thesis, she won the prize Maria Grazia Cutuli. She witnessed and covered for Italian and international newspapers the events that led to the outbreak of January 25th revolution. In June 2011, she published a book entitled I ragazzi di Piazza Tahrir. For her reportage, she won the 2012 journalistic price Ivan Bonfanti. She is a scientific coordinator of Arab Media Report and a researcher at the Italian Istituto Affari Internazionali, IAI.fr 